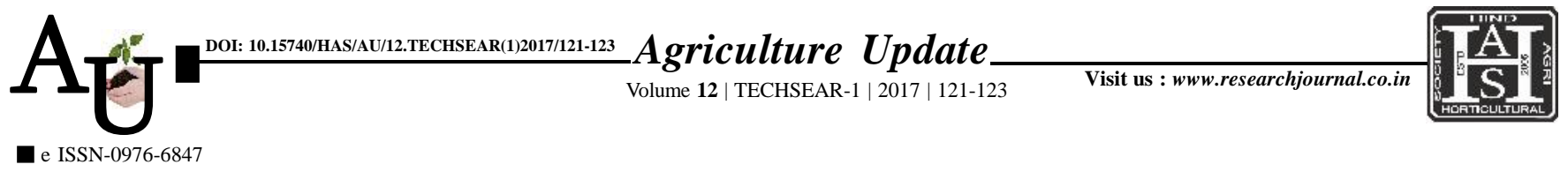

\title{
Research Articiz: Influence of rice establishment technique on growth and yield of paddy (CO51)
}

\author{
M. SUGANTHI, GAYATHRI SUBBIAH, R. VENKATRAMANAN, P. \\ KUMARAVEL AND H. GOPI
}

Article Chronicle: Received :

05.07.2017;

Accepted :

22.07.2017
KEY WoRDS :

Rice, Machine

planting, SRI, Drum

seeding, Yield,

Economics

Author for correspondence :

\section{SUGANTHI}

Post Graduate Research Institute in Animal

Sciences, Kattupakkam,

TANUVAS (T.N.) INDIA

Email:agrisuganthi@yahoo.

com

See end of the article for authors' affiliations
SUMMARY : The field experiment was conducted at Krishi Vigyan Kendra Kattupakkam Tamil Nadu, India during Rabi (Oct-Mar) seasons of 2014-15 to study the different crop establishment techniques on growth yield and economics of new variety of rice (CO-51). The experiment was laid out with unpaired $t$ test design. The treatment of drum seeding technique was compared with SRI square planting. Among the crop establishment techniques, SRI square planting significantly influenced the growth and yield characters and yield of paddy crop. The maximum plant height, number of tillers hill1, grain yield, straw yield were recorded under SRI square planting during Rabi. The lowest grain yield, straw yield were recorded under drum seeding technique.

How to cite this article : Suganthi, M., Subbiah, Gayathri, Venkatramanan, R., Kumaravel, P. and Gopi, H. (2017). Influence of rice establishment technique on growth and yield of paddy (CO51). Agric. Update, 12(TECHSEAR-1) : 121-123; DOI: 10.15740/HAS/AU/12.TECHSEAR(1)2017/121-123. 